\title{
耐候性評価用リファレンス試験片の実験室光源暴露による特性評価 CHARACTERIZATION OF WEATHERING REFERENCE MATERIALS BASED ON LABORATORY LIGHT SOURCE EXPOSURE ENVIRONMENT
}

\author{
高根由充*, 樫野紀 元**, 渡辺 寧*** \\ Yosimitsu TAKANE, Norimoto KASHINO and Yasushi WATANABE
}

\begin{abstract}
Three kinds of weathering reference materials namely polyethylene, polycarbonate and poly(ethylene terephthalate) were investigated their characteristics for temperature and ultraviolet radiation using by xenon arc and open flame carbon arc exposure devices with changing their chamber temperature, uv intensity and filters: Activation energy and power number of uv regression analysis were calculated. As the results, polyethylene has large temperature dependency while the effect of uv intensity is rather small. On the contrary, in case of polycarbonate and poly(ethylene terephthalate), the effect of temperature and uv are quite different from polyethylene. These materials were also exposed in spectro-uv exposure device. It is recognized that polyethylene has no spector-uv dependency but polycarbonate and poly(ethylene terephthalate) have large spectro-uv dependency. From these experiments, we can select reference materials based on the effect of temperature and uv.
\end{abstract}

Keywords: reference material, carbonyl index, laboratory light source exposure test, accelerated weathering test, ,polymeric materials, weatherability リファレンス試験片、カルボニルインデックス、実験室光源暴露試験、促進暴露試験、プラスチック材料、而候性

\section{1. 序}

高分子系建築材料や塗料などの重要な特性の一つである耐候性は、 建築物の長期使用に関る重要な特性であり、寒冷地から熱帯まで幅 広い気候変化や四季の変化、また、時々刻々と環境が変化する複雑 な場での特性を評価することが求められる。耐候性における主要な 劣化因子は、太陽光線に含まれる紫外線、及び赤外線による輻射熱、 降雨や結露による水分などであり、さらには大気污染物質や酸性雨 などの関与も考えられる。これらが相乗的、複合的に作用するため、 単一の劣化因子との関係だけでは変化を説明できない場合が多く、 耐候性の評価を困難なものにしている。そこで、何らかの基準にな る材料（リファレンス試験片）によって暴露された環境を定量的に 表す試み 1 、2)が行われている。定期的に試料を回収する段階を、暴 露ステージ」というが、リファレンス試験片の暴露後の変化が、柴 外線や気温等による複合的な劣化環境を定量的に表すパラメータと なり得ることから、リファレンス試験片の特性変化を新たな「暴露 ステージ」として使用することを筆者らは提案している ${ }^{3)}$

しかし、高分子系建築材料の耐候性を評価するためにリファレン ス試験片を利用する場合は、リファレンス試験片自身の紫外線や熱 に対する反応性を理解し、建築材料の劣化反応と比較可能な情報が 不可欠である。そこで、本報では紫外線と熱が同時に作用する環境 においてリファレンス試験片がどのような特性を示すのかを明らか
‘にするため、(1)実験室光源暴露試験でのリファレンス試験片の温度、 (2) 実験室光源暴露試験での紫外線と熱の相乗作用における温度依 存性と(3)紫外線照度依存性、及び(4)照射された紫外線の波長に対寸 る依存性を求める実験を行った。また、現在の耐候性試験規格 ${ }^{4,5,6)}$ では太陽光を模擬する方法とガラス下の太陽光を模擬する方法が規 定されているが、使用されるフィルターは特性が異なるいくつかの 種類が使用されている。そこで、リファレンス試験片によってこれ らの違いを評価するため、また、太陽光との比較を行うため、実験 室光源暴露試験に使用されるフィルターの種類の影響、及び経時変 化の影響について実験を行い、リファレンス試験片を耐候性評価に 使用寸るための基礎的な考察を行った。

\section{2. リファレンス試験片}

以下の 3 種類の圾験片 (ポリエチレン、ポリカーボネート、ポリ エチレンテレフタレート) をリファレンスとして用いた。

(1)ポリエチレン' (Polyethylene, 以下、PEという。) 分子内に二 重結合(-C=C-)を導入した高密度ポリエチレンで厚さ $0.2 \mathrm{~mm}$ のフ イルムである。暴露によって容易に酸化されカルボニル基（> $\mathrm{C}=\mathrm{O}$ ）を生成する。これを赤外分光分析の吸収スペクトルから、 $1715 \mathrm{~cm}^{-1}$ 付近のカルボニル基及び $2020 \mathrm{~cm}^{-1}$ 付近のメチレン基 $\left(-\mathrm{CH}_{2}-\right)$ の吸光度を求め、メチレン基に対するカルボニル基の比

\footnotetext{
*財)日本ウェザリングテストセンター 部長

** 市立前橋工科大学 教授・工博

*** 渡辺技術事務所
}

Director, Japan Weathering Test Center

Prof., Maebashi Institute of Technology, Dr. Eng.

Consultant 
(以下、カルボニルインデックス, Carbonyl Index, $C I_{\mathrm{PE}}$ という。) を計算する。測定機器は 日本分光検製 FT/IR-420 型を用いた。こ の試験片は(財)日本ウエザリングテストセンターから入手できる。 (2)ポリカーボネート (Polycarbonate, 以下、PC という。) 耐候処 方のされていない、厚さ $0.2 \mathrm{~mm}$ のフィルムを $50 \times 15 \mathrm{~mm}$ に裁断 し使用した。暴露初期に光の照射によって、主鎖中の酸素がベン ゼン核の $\alpha$ 位に移動する光フリース転移により黄変する ”。の 変化を暴露前後の紫外・可視吸収スペクトルを測定し、290nm で の吸光度の暴露前後の差 ${ }^{2)}: \triangle A 290_{\mathrm{pC}}$ として求める。測定機器は 日本分光株製 V-570 型を用いた。この試験片は帝人化成侏製の一 般屋内用フィルムとして市販されている。

(3)ポリエチレンテレフタレート (Poly(ethylene terephthalate)以下、 PET という。）耐候処方のされていない厚さ $0.025 \mathrm{~mm}$ のフィル ムを $50 \times 15 \mathrm{~mm}$ に裁断し使用した。暴露によって水酸基 (-OH) やカルボニル基（>C=O）などの官能基を生成すると言われてい るク。また、湿度の高い雾囲気下では加水分解が起こる。暴露前 後の紫外可視吸収スペクトルを測定し、330nm での吸光度の暴露

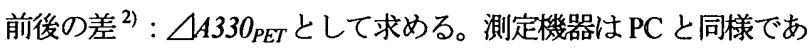
る。この試験片はユニチ力侏製 S-25 として市販されている。 色はPE が灰白色で不透明、PC と PET は無色透明である。

\section{3. 実験}

3. 1 リファレンス試験片の特性に関する実験

(1)実験室光源暴露試験での試験片温度の測定

実験室光源暴露圾験における試験片の温度は、熱の影響を評価す るために不可欠な情報である。そこで、0.1 $\mathrm{mm}$ の熱電対を試験片の 裏面に貼り付け、試験片温度を測定した。

装置はキセノンアーク灯を使用し、照度を60、120 及び $180 \mathrm{~W} / \mathrm{m}^{2}$ の3 段階に変え、それぞれの照度の時に槽内温度を $30 、 40$ 及び $50^{\circ} \mathrm{C}$ に設定した。試験片ドラムの回転を止めた状態で点灯し、照度と槽 内温度が安定した約 30 分後に温度を読み取った。使用機器はスカ試 験機㑣製キセノンウエザーメーターSX75 型、フィルターは屋外の 太陽光を模擬する組合せである内側が石英、外側が紫外透過フィル ター\#275である。

(2)紫外線と熱の相乗作用における温度の影響

紫外線と熱が同時に作用する環境において、環境条件の定量評価 にリファレンス試験片を使用するためには、それぞれの因子がどの ように影響するのかを把握しておく必要がある。そこで先ず、紫外 線が照射されている間の温度の影響を評価するため、キセノンアー ク灯を使用し、紫外線照度を一定にして、槽内温度を 3 段階に変化 させる実験 ')を行った。

試験条件は紫外線照度を $60 \mathrm{~W} / \mathrm{m}^{2}(300 \sim 400 \mathrm{~nm})$ 一定として、槽

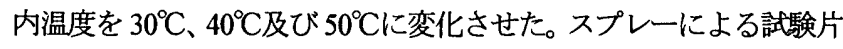
温度の低下を除くためスプレーは無しとした。試験片は 3 段式ホル ダーの中央にセットし、他の空きスペースは白色紙で覆った。使用 機器は 3.1(1)と同様である。

(3)紫外線と熱の相乗作用における紫外線照度の影響

次に紫外線照度に対する反応性を評価するため、キセノンアーク 灯を使用し、一定温度で紫外線照度を 3 段階に変化させる実験 ${ }^{1) を ~}$
行った。

キセノンアーク灯は照度を上げても分光分布が相似的に変化する と考えられるため、槽内温度を $40^{\circ} \mathrm{C}$ 一定にし、照度を $45 \mathrm{~W} / \mathrm{m}^{2} \sim$ $120 \mathrm{~W} / \mathrm{m}^{2}$ の間で数段階に変化させた。他の条件は前項と同様である。 (4)分光依存性

太陽光中に含まれる $300 \mathrm{~nm}$ 以下の短波長紫外線の割合は極わず かであるが、実験室光源暴露試験では使用するフィルターによって 若干の短波長紫外線を含んでいる。したがって、屋外暴露と実験室 光源暴露の違いを検討寸るためにはリファレンス試験片自身の分光 特性を明らかにする必要がある。そこで、分光照射装置により分光

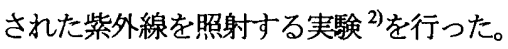

使用機器はスガ試験機株製分光老化試験機 SPW7 型で、この装置 は220〜 520 $\mathrm{nm}$ の範囲の紫外線を幅 $160 \times 15 \mathrm{~mm}$ の大きさの試料に分 光して照射する。したがって、試験片の幅 $1 \mathrm{~mm}$ に対して $2 \mathrm{~nm}$ の分 光紫外線を照射することができる。この装置に試験片を 10 時間及び 20 時間暴露した後、分光光度計内で試験片を 5 10 10 m 毎 (分光紫 外線として 10〜20nm 毎）にずらして吸光度を測定した。

3. 2 フィルターの影響に関する実験

(1) フィルターの種類の影響

JIS A 1415 (高分子系建築材料の㬰験室光源暴露試験方法) では光 源として、キセノンアーク灯、オープンフレームカーボンアーク灯 (サンシャインカーボンともいう。)、柴外線カーボンアーク灯、紫 外線営光灯が規定されている。これらの光源のうち、キセノンアー ク灯とオープンフレームカーボンアーク灯については、太陽光を模 擬する方法とガラス越しの太陽光を模擬する方法が規定されている。 しかし、紫外線のカットオン波長（ピーク透過率の $5 \%$ になる波長） は規定がないため、色々な種類のフィルターが使用されている。そ こで、現在、最も多く使用されるこの二つの光源で試験を行う際の リファレンスとして利用寸るため、また、実際の太陽光との比較の ため、各種光源の各種フィルターによる実験 ")を行った。使用した フィルターは太陽光を模擬するタイプである。種類を Table1 に示す。 使用機器はキセノンアーク灯ではスガ試験機森製 SX75 型及びア トラス社製 Ci4000 型を、オープンフレームカーボンはスガ試験機棒 製 WEL-SUN-HCH 型を使用した。

試験条件はキセノンではJS K 7350-2（プラスチックー実験室光 源による暴露試験方法 第 2 部 : キセノンアーク光源) により照度 を $60 \mathrm{~W} / \mathrm{m}^{2}\left(300 \sim 400 \mathrm{~nm} 、 \mathrm{SX} 75\right.$ 型について)、または $0.5 \mathrm{~W} / \mathrm{m}^{2}(340 \mathrm{~mm}$ 、 $\mathrm{Ci} 4000$ 型について)、ブラックパネル温度 $63^{\circ} \mathrm{C}$ 、但し、スプレーに よる温度の低下を除くためスプレーは無しとした。オープンフレー ムカーボンはJS K 7350-4（プラスチックー実験室光源による暴露 試験力法 第 4 部: オープンフレームカーボンアークランプ）によ り照度が約 $80 \mathrm{~W} / \mathrm{m}^{2}(300 \sim 400 \mathrm{~nm}$ ) (換算值) ブラックパネル温度

Table 1 Kinds of used filters

\begin{tabular}{|c|c|c|c|}
\hline Light so & & inner & outer \\
\hline \multirow{3}{*}{ Xenon } & 1 & borosilicate Type-S & borosilicate Type-S \\
\hline & 2 & $\begin{array}{l}\text { Coated InfraRed Absorbing } \\
\text { (CIRA) quartz }\end{array}$ & soda lime glass \\
\hline & 3 & Quartz & $\begin{array}{l}\text { Uv absorbing glass } \\
\# 275\end{array}$ \\
\hline \multirow[t]{2}{*}{ Carbon } & 1 & \multirow{2}{*}{\multicolumn{2}{|c|}{ Atype (JIS B 7753、 same as I type of ISO 4892-4) }} \\
\hline & 2 & Btype (JIS B 7753、 same as II type of ISO 4892-4) & \\
\hline
\end{tabular}


$63^{\circ} \mathrm{C} 、$ スプレーは無しである。

(2)光源とフィルターの経時変化の影響

キセノンアーク灯はランプとフィルターの経時的な変化のため、 紫外部の分光エネルギーが変化することが知られている。そこで、 一定時間毎にリファレンス試験片を照射し、ランプフィルターシス テムの経時変化がリファレンス試験片の変化に及ぼす影響について 検討した。

試験条件は 3，2項(1)と同様、JIS K 7350-2 により、紫外線照度

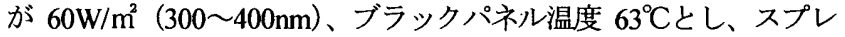
一は 120 分中 18 分噴霧、フィルターは屋外の太陽光を模擬する内側 が石英、外側が紫外透過フィルター\#275 を使用した。使用機器は スガ訌験機㑣製 WEL6X 型である。

この条件で試験片を 120 時間毎に交換する暴露を 17 回繰返し、ラ ンプが新しい時期から使用限界時間に近い 2040 時間まで繰り返し た。この試験では試験槽内には様々なサンプルが混在する一般的な 状態で行った。

\section{4. 結果と考察}

\section{1 試験片温度}

試験片温度の測定結果を Table2 に示す。試験片間の差は認められ ない。槽内温度の実測值と試料温度の差は照度が高くなるとわずか に拡大し、照度が $60 \mathrm{~W} / \mathrm{m}^{2}$ の時は $1^{\circ} \mathrm{C}$ 程度、 $180 \mathrm{~W} / \mathrm{m}^{2}$ の時は最大 $2.5^{\circ} \mathrm{C}$ 程度の差が見られる。槽内温度の設定值と実測值はどの条件でも $1^{\circ} \mathrm{C}$ 以内となっている。今回の測定は試験片ドラムを止めた状態で測 定していることと誤差を考慮すると、通常の運転状態では試験片の 温度は槽内温度、または、槽内温度設定值よりもわずかに高い程度 と考えられる。

\section{2 温度依存性}

Fig.1 に PE、PC 及び PET の紫外線照度一定時の特性変化に及ぼ す温度の影響を示す。(図中に示した温度は槽内温度設定值である。） どの条件でも各試験片の特性值と暴露時間の関係は直線関係が得ら れた。したがって、各試験片の特性值は暴露された環境と比例して いるということができ、暴露された環境を定量評価できることを示 している。この各直線の傾きはそれぞれの条件での反応速度と考え ることができる。この反応速度の対数と試料温度の逆数の関係を、 いわゆるアレニウスプロットすると Fig. 1の右側のようにどの試験 片も直線関係が得られる。したがって、この関係は次のように表さ れ、直線の傾きから活性化エネルギーを(1)式から計算することがで きる。

Table 2 Surface temperature of reference specimens $\left({ }^{\circ} \mathrm{C}\right)$

\begin{tabular}{c|c|c|c|c|c}
\hline Irradiance & $\begin{array}{l}\text { Setting } \\
\text { temperature } \\
\text { of chamber }\end{array}$ & $\begin{array}{l}\text { Chamber } \\
\text { temperature }\end{array}$ & PE & PC & PET \\
\hline \multirow{3}{*}{60} & 30 & 30.0 & 30.6 & 30.6 & 30.4 \\
\cline { 2 - 6 } & 40 & 40.1 & 40.8 & 40.5 & 40.9 \\
\cline { 2 - 6 } & 50 & 49.1 & 50.3 & 50.6 & 50.8 \\
\hline \multirow{3}{*}{120} & 30 & 29.9 & 31.3 & 31 & 31 \\
\cline { 2 - 6 } & 40 & 39.6 & 41 & 41.3 & 41.2 \\
\cline { 2 - 6 } & 50 & 50.1 & 51.3 & 51.8 & 51.7 \\
\hline \multirow{3}{*}{180} & 30 & 30.3 & 31.9 & 31.1 & 31.6 \\
\cline { 2 - 6 } & 40 & 39.9 & 41.6 & 41.9 & 41.9 \\
\cline { 2 - 6 } & 50 & 49.1 & 51.1 & 51.6 & 51.5 \\
\hline
\end{tabular}
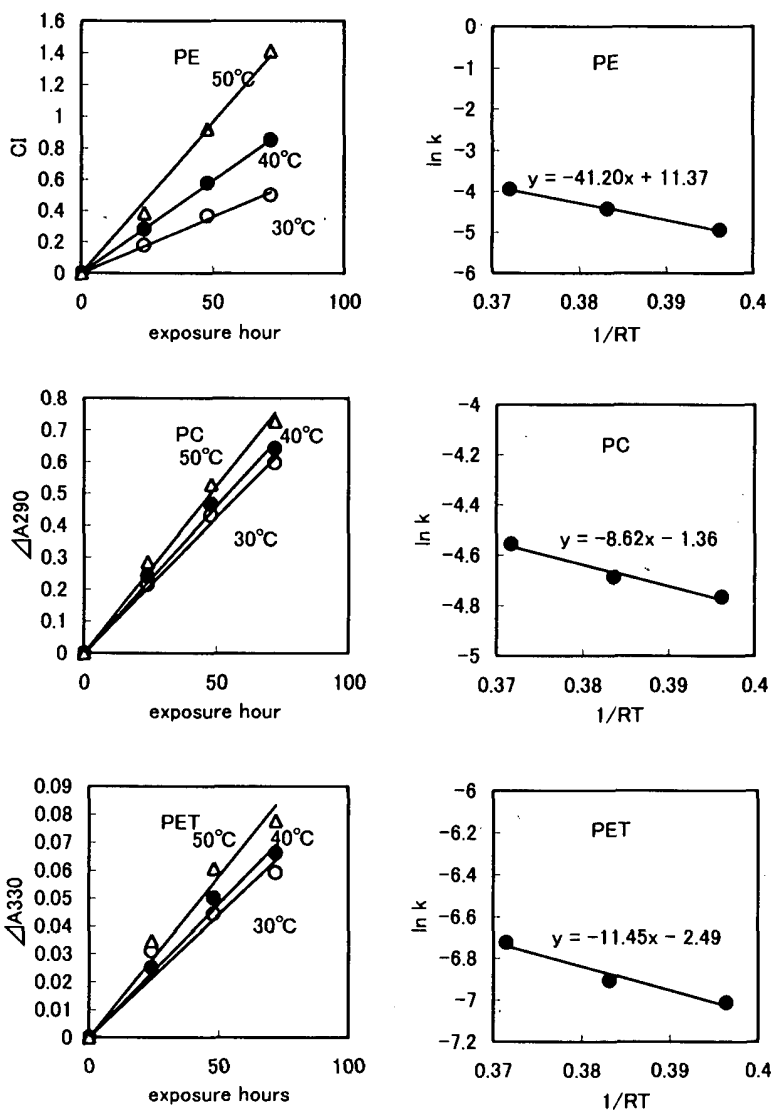

Fig. 1 Temperature dependency of reference specimens and correlations between degradation speed and reciprocal surface temperature of reference specimens at constant uv intensity $60 \mathrm{~W} / \mathrm{m}^{2}$

Ln $\mathrm{k}=\mathrm{A} \cdot \mathrm{E} / \mathrm{RT} \cdots \cdots(1)$

ここで、 $\mathrm{k}:$ 各条件での直線の傾き

$\mathrm{E}:$ 活性化エネルギー

$\mathrm{R}:$ ガス定数

A : 定数

$\mathrm{T}:$ 試料温度

それぞれの直線関係から活性化エネルギーを計算すると、CI $I_{P E}$ は $41.20 \mathrm{KJ} / \mathrm{mol} 、 \triangle A 290_{P C}$ は $8.62 \mathrm{KJ} / \mathrm{mol} 、 \triangle A 330_{P E T}$ は $11.45 \mathrm{KJ} / \mathrm{mol}$ とな った。PEが最も温度の変化に対しての反応性が大きく、20を基淮 として $10^{\circ} \mathrm{C}$ 試験片温度の上昇で変化速度が何倍になるかを(2)式 のように計算すると約 1.7 倍になる。一方、 $\triangle A 290_{P C}$ が最も活性化 エネルギーが小さく、温度の変化にはあまり大きく影響されず、 $10^{\circ} \mathrm{C}$ の訊験片温度の上昇でも変化速度は約 1.1 倍、 $\triangle A 330_{P E T}$ は 1.2 倍と なる。

$\mathrm{k}_{30} / \mathrm{k}_{20}=\exp \left(-\mathrm{E}^{-\mathrm{RT}_{30}}\right) / \exp \left(-\mathrm{E} / \mathrm{RT}_{20}\right) \cdots \cdot(2)$

ここで、 $\mathrm{k}_{30 、} \mathrm{k}_{20}$ : それぞれ $30^{\circ} \mathrm{C}$ と $20^{\circ} \mathrm{C}$ のきの反応速度

試験片毎に温度に対する反応性が異なる理由は次のように考えら れる。プラスチックの劣化形態は、ポリマーの運動にかかわるガラ ス転移温度や融点を境に大きく変わる ${ }^{8)}$ 。ポリエチレンのガラス転 移温度は $-85^{\circ} \mathrm{C}$ 付近 ${ }^{9)}$ 、ポリカーボネートは $155^{\circ} \mathrm{C}$ 付近、ポリエチ 

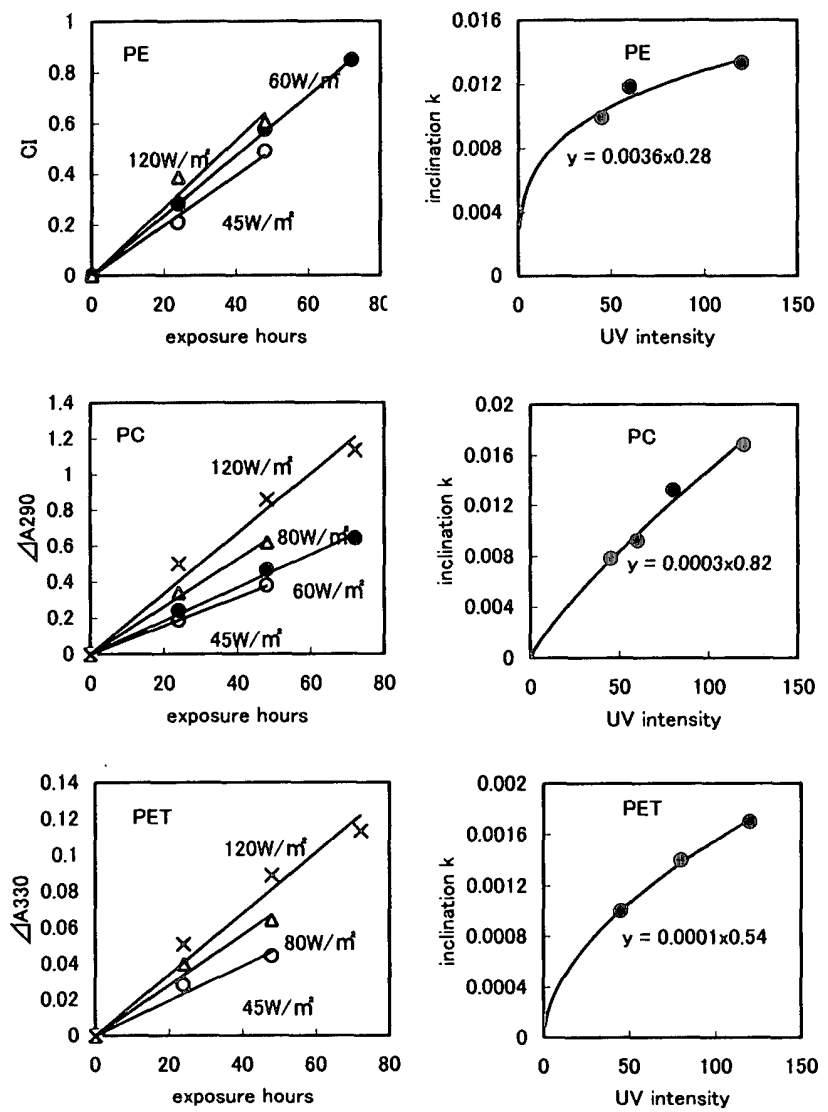

Fig. 2 UV intensity dependency of reference specimens and correlation between irradiance and degradation speed at constant chamber temperature $40^{\circ} \mathrm{C}$

レンテレフタレートは $80^{\circ} \mathrm{C}$ 付近である。したがって、ポリエチレン は常温では常にガラス転移温度以上であり、分子が運動しやすくポ リマー分子のミクロ分子運動の増大に伴い、酸素の拡散が促進され ること ${ }^{10)}$ により温度依存性が大きいと考えられる。ポリカーボネー 卜は非晶性ポリマーであり、ベンゼン環に基づく剛直性、分子構造 の繰り返し単位の大きさのために分子配列しにくいことが結晶化し にくい理由とされている。この主鎖の動きにくさが $150^{\circ} \mathrm{C}$ 前後の高 いガラス転移温度を与えており ${ }^{11)}$ 、温度依存性の小さい理由と考え られる。今回使用した 3 種類のフィルムの活性化エネルギーとガラ ス転位温度はよく対応している。

\section{3紫外線照度依存性}

Fig.2 に PE、PC 及び PET の特性変化に及ぼす放射照度の影響を 示す。槽内温度は $40^{\circ} \mathrm{C}$ 一定である。各試料とも、どの放射照度でも 直線関係が見られ、暴露環境と比例している。しかし、放射照度と の関係は試料毎に異なり、PE は照度を上げてもそれほど大きく変化 していない。そこで、放射照度の影響を定量的に表すため、速度定 数は温度一定のもとでは(3)式のように放射照度の関数として表せ $ろ^{12)}$ と仮定して照度に対するべき乗数を回帰分析から求めた。

$\mathrm{I}=\mathrm{CU}^{\alpha} \ldots . .(3)$

ここで、I : 吸光度

$C:$ 定数

$\mathrm{U}:$ 紫外線照度

\section{$\alpha:$ べき乗数}

Fig.2 の右側に回帰分析結果を示す。PE は放射照度に対して 0.28 乗、PCは 0.82 乗、PET は 0.54 乗という結果が得られた。

これらのべき乗数及び前項の活性化エネルギーは既報 ${ }^{3)}$ で述べ た「小池田中モデル式」の係数とよく対応している。係数そのもの は一致しないが、これは屋外暴露と実験室光源暴露の条件の違いに よる柴外線の分光分布や、試料温度の違いなどによるものと考えら れる。放射照度に対する反応性、温度に対する反応性はどちらの暴 露試験結果からも同じ傾向が得られた。

PE のべき乗数が小さく、紫外線照度の影響が小さい理由として次 のように考えられる。ポリエチレンにはもともと $290 \mathrm{~nm}$ 以上の紫外 線を直接吸収する官能基がないため、太陽光による紫外線劣化は起 こらないはずであるが、実際は成形加工中の触媒残渣や微量金属な どが含まれていると劣化が起こる ${ }^{8)}$ 。今回使用した PE はトランス ビニレン基が導入されているため、トランスビニレン基に隣接寸る C-H 結合の結合解離エネルギーが低くなっている $(77 \mathrm{Kcal} / \mathrm{mol})^{10)}$ 。 $300 \mathrm{~nm}$ の紫外線の持つエネルギーは $95 \mathrm{Kcal} / \mathrm{mol}$ であるので、 C-H 結 合を切断するには十分なエネルギーを持っており、紫外線の照射に より容易に C-H 結合が切断され、ラジカルが生成した後は自動酸化 反応によって劣化する ${ }^{8)}$ 。したがって、紫外線の影響は酸化反応の 開始過程にあり、また、結合解離エネルギーが低いため照度はあま り影響しないと考えられる。

ポリカーボネートやポリエチレンテレフタレートは構成単位その ものが柴外線を吸収するとともに、劣化して紫外光を吸収する化合 物を生成寸る $^{8)}$ ようになるため、紫外線の影響が大きいと考えられ る。

4. 4 分光特性

分光分布を持った光に対する分光依存性を正しく評価するために は、光の強さの影響と区別するために各波長の放射露光量が同一に なるように補正しなければならない。そこで、一定波長間隔每の紫 外線の照度をキセハン光の分光分布のチャート紙から求め、ある波 長の光を照射した時のリファレンス訊験片の吸光度を、同じ波長の キセノン光の放射露光量で除して補正した。Fig.3に各試料の特性変 化と紫外線波長の関係を示す。

$\mathrm{PE}$ は波長が短くなるほど $C I_{P E}$ の值は大きくなり、特定波長の影響 は見られないここの結果は 4.3 と同様にC-H 結合の結合解離エネ ルギーよりも紫外部のエネルキ゚ーが短波長ほど大きいためと考えら れる。

$\triangle A 290_{P C}$ は310nm以下の光で大きく変化し $290 \mathrm{~nm}$ 付近の光によっ て最も大きく変化している。また、 $340 \mathrm{~nm}$ 以上の光ではほとんど変 化していない。この結果は転位生成物の生成に基づくものと酸化生 成物による可能性が指摘されている ${ }^{8)}$ 。

$\triangle 4330_{P E T}$ は $330 \mathrm{~nm}$ 以下の光で変化し $310 \mathrm{~nm}$ 付近にピークがあり、 また、340nm 以上の光ではほとんど変化していない。この変化は一 $\mathrm{COOH}$ 末端基の生成、主鎖の切断等を示すものの可能性が指摘されて (るる)。

これら 3 種類の樹脂の分光特性は村山らが行った実験 ${ }^{13)}$ とほぼ一 致し、また、Gugumus のデータ ${ }^{14)}$ とも一致することから、これらの 分光依存性はこれらの樹脂に固有の性質と考えられる。 

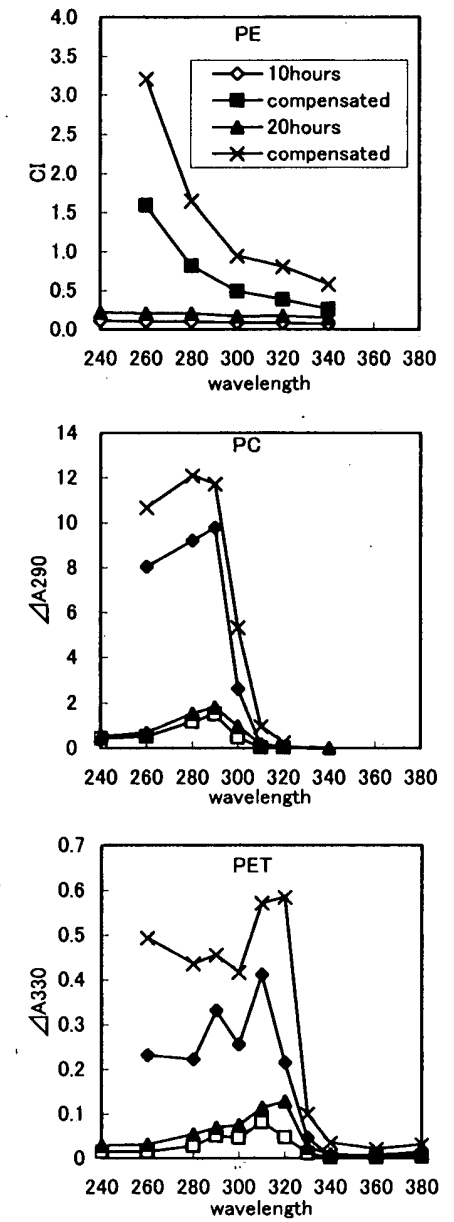

Fig.3 Spectral UV dependency of reference specimens
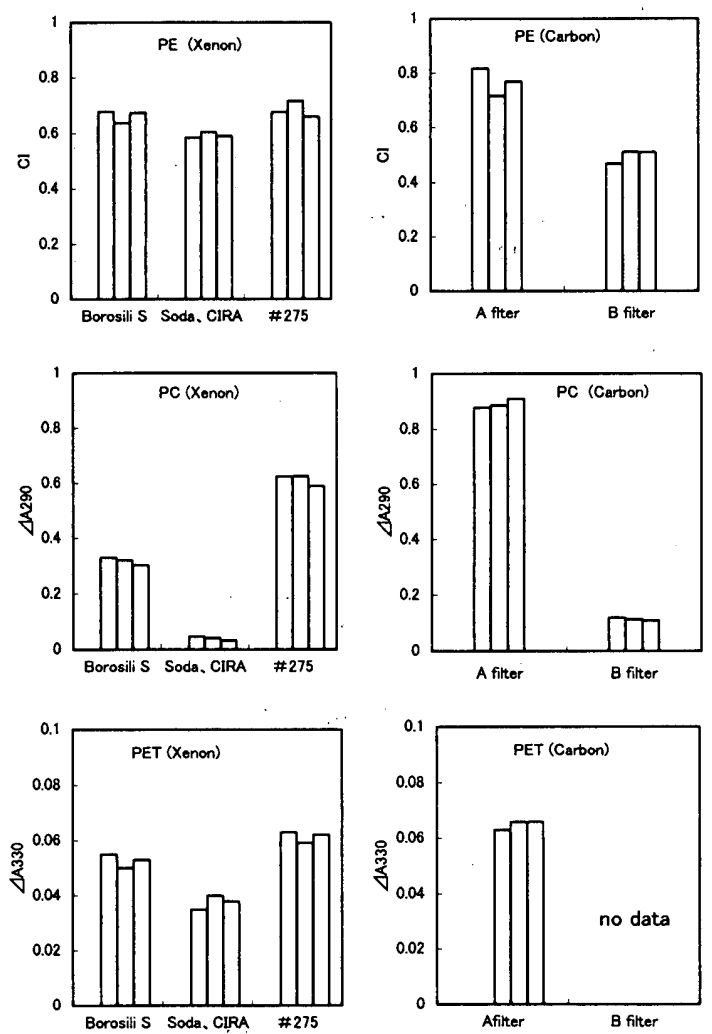

Fig 4 The change of reference specimens based on light source and filters
Table 3 Exposure test results by different filter and lamps

\begin{tabular}{|c|c|c|c|c|c|}
\hline $\begin{array}{c}\text { Light } \\
\text { sources }\end{array}$ & filters & $\mathrm{n}$ & $C I_{P E}$ & $\angle A 330_{P C}$ & $\triangle A 330_{P E T}$ \\
\hline \multirow{12}{*}{ Xenon } & \multirow{4}{*}{$\begin{array}{l}\text { Brosili-S } \\
\text { Brosili-S }\end{array}$} & 1 & 0.678 & 0.330 & 0.055 \\
\hline & & 2 & 0.638 & 0.322 & 0.050 \\
\hline & & 3 & 0.673 & 0.303 & 0.053 \\
\hline & & Av. & 0.663 & 0.318 & 0.053 \\
\hline & \multirow{4}{*}{$\begin{array}{l}\text { CIRA } \\
\text { Soda } \\
\text { lime }\end{array}$} & 1 & 0.584 & 0.047 & 0.035 \\
\hline & & 2 & 0.604 & 0.041 & 0.040 \\
\hline & & 3 & 0.590 & 0.033 & 0.038 \\
\hline & & Av. & 0.593 & 0.040 & 0.038 \\
\hline & \multirow{4}{*}{$\begin{array}{l}\text { Quartz } \\
\# 275\end{array}$} & 1 & 0.676 & 0.625 & 0.063 \\
\hline & & 2 & 0.716 & 0.626 & 0.059 \\
\hline & & 3 & 0.660 & 0.590 & 0.062 \\
\hline & & Av. & 0.684 & 0.614 & 0.061 \\
\hline \multirow{8}{*}{ Carbon } & \multirow{4}{*}{ A type } & 1 & 0.786 & 0.877 & 0.063 \\
\hline & & 2 & 0.776 & 0.884 & 0.066 \\
\hline & & 3 & 0.749 & 0.908 & 0.066 \\
\hline & & Av. & 0.770 & 0.890 & 0.065 \\
\hline & \multirow{4}{*}{ B type } & 1 & 0.468 & 0.120 & no data \\
\hline & & 2 & 0.511 & 0.114 & no data \\
\hline & & 3 & 0.510 & 0.109 & no data \\
\hline & & Av. & 0.496 & 0.114 & no data \\
\hline
\end{tabular}

Fig.4〜Fig.5 及び Table3 にキセノン及びオープンフレームカーボ ンにより各試験片を 60 時間照射した結果を示す。

キセノンの試験条件は前述したように照度は一定である。また、 ランプとフィルターは新品を使用している。したがって、各試験片 の試験結果の違いは使用するフィルターのカットオン波長による違 いと考えられる。

使用したフィルターのカットオン波長は公表された值はないが、 透過率が 0\%から立ち上がってくるいわゆる立ち上がり波長はキセ ノンのボロシリケートタイプ S の場合は約 $290 \mathrm{~nm}$ 、内側 CIRA 外 側ソーダライムとの組み合わせでは約 $300 \mathrm{~nm}$ と言われている。内側 石英、外側井275 タイプでは 275nm（カタログ值）である。オープ ンフレームカーボンは A 型（カタログ值 255nm）と B 型（カタログ 值 275nm）である。

Fig.4 からキセノンによる $C I_{P E}$ の場合はフィルター間でそれほど 大きな差はないが、オープンフレームカーボンでは $\mathrm{A}$ 型の変化が大 きい。 $\triangle A 290_{P C}$ はフィルタちによる違いが顕著であり、いわゆる立 ち上がり波長とよく対応している。 $\triangle A 330_{P E T}$ もフィルターによる違 いが見られる。

Fig.5 は光源とフィルターが異なる条件で暴露されたPC とPET の 紫外吸収スペクトルである。比較のために屋外で暴露されたフィル 厶の值 (銚子の 2000 年 8 月の 1 ヶ月間) も示した。このチャートか ら PC は $290 \mathrm{~nm}$ の吸光度の、PET は $330 \mathrm{~nm}$ の吸光度を読み取り、試 験前後の差を計算して Fig.4 と Table3 に示している。

$\mathrm{PC}$ は350nm 付近から $300 \mathrm{~nm}$ 付近にかけて $320 \mathrm{~nm}$ 付近に極大を示 しながら全体のスペクトルが上昇する。特にオープンフレームカー ボンの A 型では変化が大きい。この変化は 4．4項と同様に転位生 成物、または、酸化物質によるもので、 $290 \mathrm{~nm}$ 付近の紫外線を照射 するとこの変化は迅速に起こる ${ }^{15)}$ 。したがって、 $\triangle A 290_{P C}$ の場合は 実験室光源暴露で使用するフィルターによって太陽光には含まれな い短波長紫外線の影響を大きく反映した結果を示すと言える。 

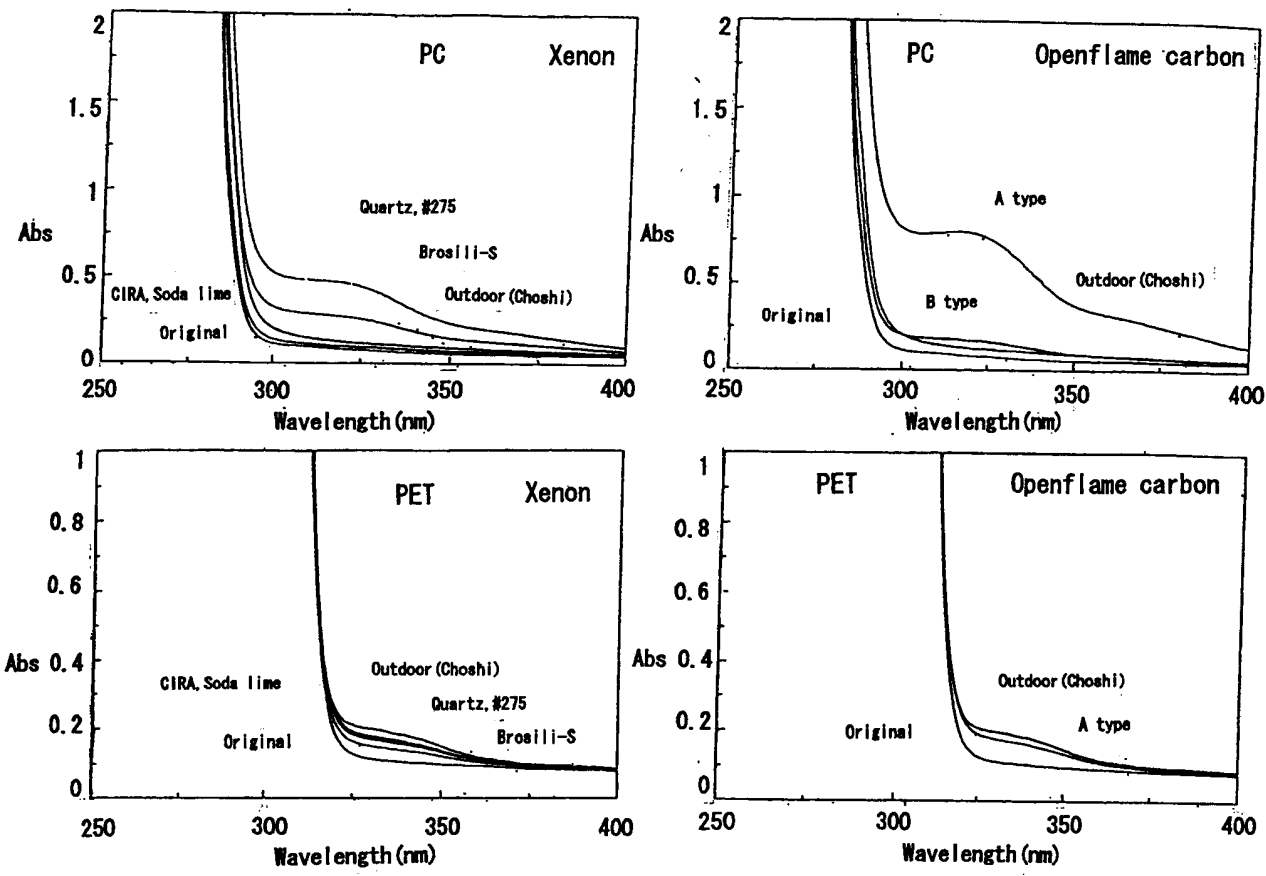

Fig.5 Difference of uv spectra of PC and PET after xenon exposure using different filters

Fig.5 の下側に示した PET に関しては、どのフィルターを使用し ても吸収スペクトルの波形は同じであり、屋外とも同様なスペクト ルの変化を示している。したがって、どのフィルターを使用しても カットオン波長に対応した結果を示していると言える。

今回の実験では両光源とも太陽光を模擬するフィルターを使用し ている。キセノンでの $C I_{P E}$ はフィルターによる劣化速度の差は小さ いが、 $\triangle A 290_{P C}$ と $\triangle A 330_{P E T}$ ではフィルターの影響が大きいこと、 オープンフレームカーボンでは $C I_{P E}$ と $\triangle A 290_{P C}$ の両者ともフィル ターの影響が顥著に見られることから、同じ分類に属するフィルタ 一を使用してもカットオン波長の違いによって、短波長部に吸収波 長のある材料は劣化速度に大きな影響を受けることが明らかである。 4. 6 光源とフィルターの経時変化の影響

キセノンによる 120 時間毎の繰返し暴露の結果を Fig6 に示す。 $C I_{P E}$ を除いて $\triangle A 290_{P C}$ と $\triangle A 330_{P E T}$ はランプとフィルターが新しい 時期からおよそ 800 時間程度まで時間が経過するにしたがって変化 が少なくなっていることが分かる。これは、時間の経過にしたがっ て紫外部の分光分布が変化し、短波長部が減少するとともに長波長 側の紫外部が相対的に増加するため（メーカー資料より読み取り） と考えられる。

キセノンアーク灯式試験機は柴外線のエネルギーを自動調節して、 ある範用内のエネルギ一、または、ある波長でのエネルギーが一定 になるように制御されている。しかし、300〜400 $\mathrm{nm}$ の間の分光分 布は長波長側のエネルギーが増加し、短波長側では减少するという 特性があるため、短波長側の紫外線で劣化する材料に関しては 300 〜 400nm の間のエネルギー、または、ある特定の波長のエネルギー が一定といっても注意が必要である。

したがって、短波長紫外線を吸収寸るような材料にとってはリフ アレンス試験片を同時に暴露して、リファレンス試験片の特性值を
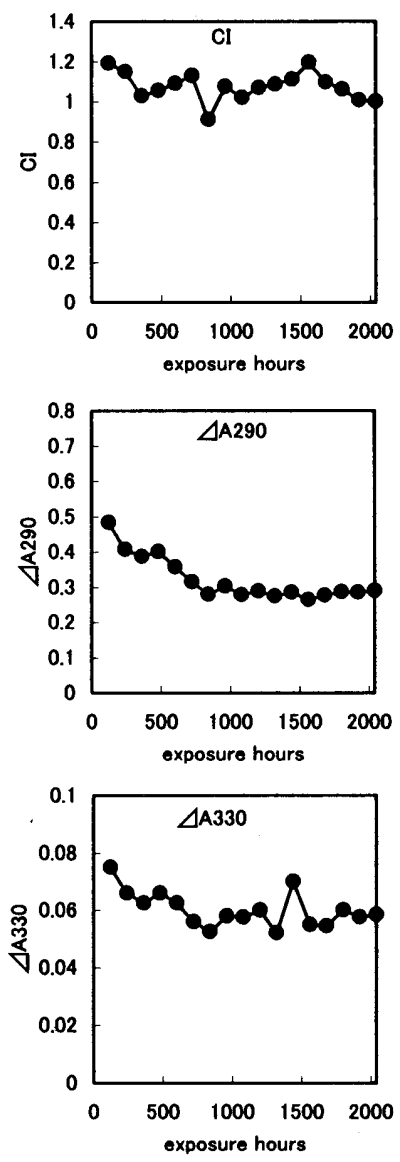

Fig 6 The change of reference specimens every 120 hours by xenon arc source exposure. 
記録しておくことが再現性の向上に有効であると考えられる。この 場合、PE は 300 400nm の範囲ではあまり大きな分光依存性を持っ ていないので 300 400nm の広帯域のモニターに使用することがで き、PC と PETはそれぞれ分光依存性を持っているため、PCは $320 \mathrm{~nm}$ 以下の紫外線のモニターに、PET は340nm 以下の紫外線のモニター に有効と考えられる。

\section{4. 結論}

以上の実験から、各リファレンス試験片の特性として以下のこと が導かれる。

1) $C I_{P E}$ は紫外線の強さにはあまり依存せず、変化速度は温度の影響 が強い。

2) $\triangle A 290_{P C}$ は紫外線のベき乗数が大きく、活性化エネルギ一が小 さいことから紫外線の影響が強い。 $\triangle A 330_{P E T}$ も同様に紫外線のべき 乗数と活性化エネルギ一から柴外線の影響が大きい。

3) $C I_{P E}$ は特別な吸収波長は無く、短波長ほど変化が早い。

4) $\triangle A 290_{P C}$ は $290 \mathrm{~nm}$ 付近で、 $\triangle A 330_{P E T}$ は $310 \mathrm{~nm}$ 付近で最も大き な変化をしている。

5) したがって、紫外線と熱の相乗作用の中で、熱の影響を大きく受 ける材料にはPEを、短波長紫外線の影響を受ける材料にはPCまた はPET をリファレンス試験片として選択することができる。

6) 実験室光源暴露試験装置のフィルターは同じ分類に属してもカ ットオン波長が異なり、リファレンス試験片の結果に差がある。

7) キセノン光源の分光分布が時間とともに変化するため、特に短波 長紫外線の影響を受ける材料にはリファレンス圾験片を同時に暴露 することは再現性の確保に有効である。

今回、リファレンス試験片の特性を明らかにする各種実験を行っ た。この結果からリファレンス試験片を選択する目安として、PEは 特定波長の紫外線の影響がなく、温度の影響が大きな材料、また、 $\mathrm{PC}$ は 320nm 以下、PET は340nm 以下の短波長紫外線に影響される 材料のリファレンスとなり得る材料であることが明らかになった。

また、実験室光源暴露試験ではフィルターの影響があること及び 光源の分光分布が経時変化を起こすことが明らかであるが、これに 関してはユーザー側では改善策の講じようがないため、リファレン ス試験片を同時に暴露することは再現性の確保の手段としても有効 である。

謝辞

本報をとりまとめるに当たり、ウエザリングワークショップ・冨 板崇氏のご助言を賜りました。ここに、深く謝意を表します。

参考文献

1) (財)日本ウエザリングテストセンター : 平成 14 年度新発電システムの標準 化江関寸る調查研究成果報告書、平成 15 年 3 月

2）（社）日本化学工業協会: 平成 12 年度過酷環境下における高分子製品の性 能評価試験方法の標政化、平成 13 年 3 月

3) 高根 由充、樫野 紀元、渡辺 富、冨板 崇: 而猴性評価用リファレン 詿験片による屋外暴露環境の定量評価、日本建築学会構造系論文集、第 578 号、2004年 4 月

4) IS0 4892-1 4:1994 Plastics -- Methods of exposure to laboratory light sources - Part 1:General Guidance. Part 2: Xenon-arc sources. Part 3: Fluorescent UV lamps, Part 4: Open-flame carbon-arc lamps

5) JIS K 7350-1〜4:1995, 96 プラスチック一実験室光源による暴露試験方法, 第 1 部 : 通則、第 2 部 : キセノンアーク、第 3 部 : 紫外線蛍光ランプ、第 4 部: オープンクームカーボンアーク

6) JS A 1415: 1999 高分子系建築材料の実験室光源による暴露試験方法

7) 大澤 善次郎 : 高分子の安定化技術、シーエムシー、2000 年 10 月

8) 大澤 善次郎 : 高分子の劣化と安定化、武蔵野クリエイト、1992 年6月

9) 桜内雄二郎 : 高分子化学教室、三共出版、1993 年3 月

10）井出文雄:材料特性の基礎と技衍動向(12V耐候性(1)、プラスチックエージ、 1999 年 5 月

11) プラスチック事典、朝倉書店、1992 年 1 月

12）峰松 陽、和田 訓:ポリマーの光劣化に対する紫外線放射照度の影響、 高分子学会崩壊と安定化研究討論会、講演要旨集 1992 年 12 月

13）村山 三樹男、矢野 彰一郎: プラスチックの耐光性に及ぼす照射波展の 影響、製品科学研究所研究報告 No,77 1976 年

14) F. Gugumus : Light stabilizers for thermoplastics, Plastics Additives Hand book (R.Gachter and H. Muller, eds.), Hauser Publishers, Munich, p.97 (1985)

15）村山 三樹男、矢野 彰一郎: プラスチックフィルムの分光劣化、製品科 学研究所研究報告 No,88 1979 年

(2004年 3 月 2 日原稿受理, 2004 年 5 月 18 日採用決定) 